\section{HTLV-II among pygmies}

SIR - Because of their low genetic drift and limited horizontal transmission, human T-cell lymphotropic viruses (HTLV-I and HTLV-II) act as markers of the movement of ancient populations ${ }^{1}$. The simian STLV-I isolates do not segregate independently of HTLV-I, suggesting that there has been horizontal transmission between nonhuman primates and man over long periods. These retroviruses are now being referred to as primate T-cell lymphotropic viruses (PTLVs). PTLVs are presumed to be of Asian origin, as the only indigenous populations with known endemicity of HTLV-II are American Indians, and also because the Asian STLV-I and Melanesian HTLV-I strains are highly divergent ${ }^{2}$. Ancestral PTLV could thus have segregated into a northern Asian branch that was carried over the Bering Strait to America to give rise to HTLV-II, and into an Indo-Malayan branch of PTLV-I to include the current Melanesian and Australian HTLV-I. From there, contacts gave rise to African STLV-I and HTLV-I, perhaps via Madagascar, which then spread in a second wave as the cosmopolitan HTLV-I (ref. 3). A study we carried out in Zaire now questions parts of this hypothesis.

Pygmies are considered to be the oldest inhabitants of central Africa. The Bambuti pygmies are the smallest people

Sera from seropositive Efe pgymies and Lese villagers on HTLV-I western blot strips enriched with recombinant proteins specific for HTLV-I and HTLV-II. S C, serum control; MTA-1, HTLV-I-specific protein; K55, HTLV-IIspecific protein; $\operatorname{rgp} 21$, recombinant transmembrane protein; native viral proteins $(P)$ are indicated on the left with their respective molecular masses in thousands. Native HTLV-I proteins and rgp21 were separated by SDS-PAGE and blotted onto nitrocellulose; the type-specific MTA-1 and K55 (Diagnostic Biotechnology, Singapore) have been slotted separately. Strips of nitrocellulose were incubated overnight with a 1:100 dilution of serum; after washing and a further incubation with goat anti-human IgG conjugated with alkaline phosphatase, the strips are reacted with 5-bromo-4-chloro-3-indolylphosphate and nitroblue tetrazolium (BCIP) NBT). Lanes a-h, HTLV-ll antibody-positive sera; lane i, HTLV-I-positive serum, lanes $a, d, f, h$ and $i$, sera from Lese villagers; lanes $b, c, e$ and $g$, sera from Efe pygmies. Five of the six HTLV-II antibody-positive sera with nearly complete HTLV-I western blot patterns (lanes $\mathrm{a}-\mathrm{c}$ and $\mathrm{e}-\mathrm{g}$ ) had a weak or absent P19 band, typically seen with HTLV-II antibody-positive sera. The pattern seen in two HTLV-II-positive Lese sera with an isolated p24 band in the HTLV-I blot (lanes $d$ and h) is seen in many cases of HTLV-II infection (D. Reed, personal communication). on Earth and the least admixed of pygmies ${ }^{4}$. The Efe are a group of the Bambuti pygmies living in the Ituri Forest of northeastern Zaire. They live in temporary encampments, often in the vicinity of Lese villages. The Lese are people with Bantu physical features but who speak a Sudanic language. Efe pygmies and Lese villagers have always had economic links ${ }^{5}$, but in the rare event that an Efe woman marries a Lese, she and her progeny are no longer part of the pygmy tribe. In 1991, during a survey of physical fitness in Nduye, a village of northern Ituri, we sampled serum from 12 Efe pygmies, all men, and 146 villagers (97 men, 49 women; 120 of them Lese). All 158 adults appeared healthy and none had antibodies against HIV-1 or HIV-2.

Sera reactive in an HTLV-I wholevirus enzyme-linked immunosorbent assay were tested by western blotting against virion HTLV-I and recombinant HTLV-I and HTLV-II specific proteins (see figure). This technique had already distinguished between HTLV-I and HTLV-II in North Americans, Jamaicans and Japanese ${ }^{6}$. In our hands it correctly identified 31 of 32 HTLV-I infections in Zaireans; it failed to type one. It also identified five subjects from Dungu (northeastern Zaire) as HTLV-II positive. Dungu is situated in the savannah north of the Ituri Forest at an aerial distance of $200 \mathrm{~km}$ from Nduye. These results are in agreement with another assay that used type-specific synthetic peptides to discriminate be-

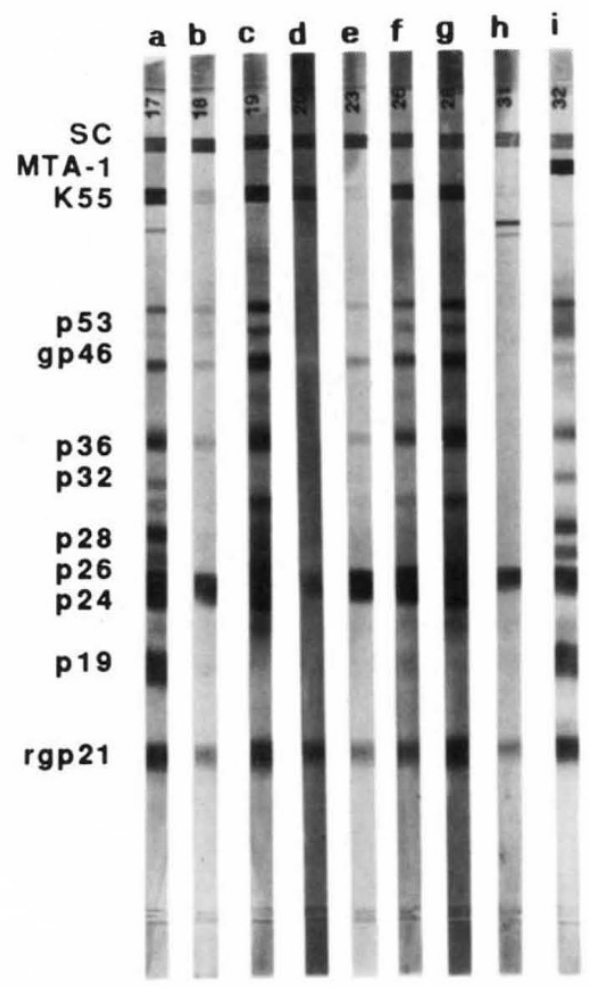

tween HTLV-I and HTLV-II (ref. 7).

Antibodies specific against HTLV-II were found in 4 of the 12 male pygmies (95\% confidence limit, 9.9-65\%) and in 4 of 120 Lese villagers ( 3 women, 1 man) (95\% confidence limit, $0.9-8.3 \%$ ) (see figure). HTLV-I was identified in one Lese man, in no pygmies, and in one woman from another ethnic group. One HTLV-positive Lese serum could not be typed.

Populations infected with HTLV-II predominantly or exclusively have not been identified before in Africa. The results are best explained by a reservoir of endemic HTLV-II in pygmies. When genomic analysis and virus isolation become feasible in the local situation it will be possible to investigate the relatedness of HTLV-II in pygmies to strains elsewhere. Contact with pygmies may be responsible for the HTLV-II we identified in five people at increased risk of sexually transmitted diseases in Dungu, but not in other areas of Zaire ${ }^{7}$, and may account for the lower prevalence of HTLV-II in the Lese villagers. Three cases of HTLV-II infection have also been reported from Gabon ${ }^{8}$ but its prevalence is low in Africa compared with HTLV-I.

The distinction between HTLV-I as an Old World and HTLV-II as a New World virus does not seem tenable. African pygmies appear to qualify with American Indians as aboriginal populations with endemic HTLV-II. There is no reason for claiming that infection in either population is older than in the other. PTLV sequences from more geographical areas and from other isolated ancient populations are needed to clarify the evolution of PTLVs. A close relative of HTLV-II has not yet been identified in simians, but if there is one it is more likely to be found in Old World primates than in feral New World monkeys, in which there is no evidence so far of either STLV or SIV.

\section{Patrick Goubau}

Jan Desmyter

Joseph Ghesquiere

Rega Institute and University Hospitals,

Katholieke Universiteit Leuven,

Minderbroedersstraat 10 ,

B-3000 Leuven, Belgium

Busaka Kasereka

Hospital of Mambasa, Ituri,

Haut-Zaire, Zaire

1. Gessain, A., Gallo, R. C. \& Franchini, G. J. Virol. 66 2288-2295 (1992)

2. Sherman, M. P., Saksena, N. K., Dube, D. K Yanagihara, R. \& Poiesz, B. J. J. Virol. 66, 2556-2563 (1992)

3. Yanagihara, R. 5th Int. Conf. HTLV, (Kumamoto, Japan, May 1992).

4. Cavalli-Sforza, L. L. in African Pygmies (ed. CavalliSforza, L. L.) 361-426 (Academic, London, 1986).

Bailey, R. C. \& Devore, I. Am. J. Phys. Anthropol. 78 $459-471$ (1989).

6. Lipka, J. J. et al. J. infect. Dis. 165, 268-272 (1992).

7. Goubau, P. et al. J. med. Virol. (in the press).

8. Delaporte, E. et al. Int. J. Cancer 49, 373-376 (1991). 